\title{
Pengaruh Tingkat Kesehatan Bank Terhadap Total Pembiayaan Bank Umum Syariah Periode 2012Q1-2020Q1
}

\author{
Sintya Prilla Rosa \\ Program Studi Ekonomi Islam Universitas Negeri Surabaya, Indonesia \\ Email: sintyaprilla@gmail.com \\ Clarashinta Canggih \\ Program Studi Ekonomi Islam Universitas Negeri Surabaya, Indonesia \\ Email: clarashintacanggih@unesa.ac.id
}

\begin{abstract}
:
This study aimed to determine the effect of bank soundess level to the total financing of Islamic Banks in Indonesia during 2012Q1 - 2020 Q1. The bank soundess level was measured by the RGEC method with Non-Performing Financing, Financing to Deposit Ratio, Board of Commissioners Size, Return on Assets and Capital Adequacy Ratio as the variables. Quantitative approach was utilized in this study through panel data regression analysis. The sample were all Islamic Banks in Indonesia. The result indicated that the Non-Performing Financing, Financing to Deposit Ratio, Board of Commissioners Size, Return on Assets, and Capital Adequacy Ratio have no effect to the total financing of Islamic Commercial Banks partially, wheras simultaneously they affect the total financing.
\end{abstract}

Keywords: Bank Soundness Level, RGEC Method, Total Financing

\section{Abstrak:}

Tujuan dari penelitian ini adalah untuk mengetahui pengaruh tingkat kesehatan bank dengan metode RGEC yang diukur menggunakan variabel Non Performing Financing, Financing to Deposit Ratio, Ukuran Dewan Komisaris, Return on Assets dan Capital Adequacy Ratio terhadap total pembiayaan bank umum syariah periode 2012Q1-2020Q1. Penelitian ini menggunakan pendekatan kuantitatif dengan teknik analisis data panel. Sampel dalam penelitian ini yakni seluruh Bank Umum Syariah yang ada di Indonesia. Hasil penelitian ini menunjukkan bahwa secara parsial variabel Non Performing Financing, Financing to Deposit Ratio, Ukuran Dewan Komisaris, Return on Assets, dan Capital Adequacy Ratio tidak berpengaruh terhadap total pembiayaan bank umum syariah. Sedangkan secara simultan, variabel Non Performing Financing, Financing to Deposit Ratio, Ukuran Dewan Komisaris, Return on Assets, dan Capital Adequacy Ratio berpengaruh terhadap total pembiayaan bank umum syariah.]

Kata Kunci: Tingkat Kesehatan Bank, Metode RGEC, Total Pembiayaan 


\section{PENDAHULUAN}

Kinerja sektor ekonomi syariah telah memperoleh capaian yang memuaskan. Namun, belum sepenuhnya mencapai target yang diinginkan. Target pengembangan perbankan syariah tercantum dalam Masterplan Ekonomi Syariah Indonesia (MEKSI) tahun 2019-2024. Dalam masterplan tersebut dikatakan bahwa pada tahun 2023 ekonomi syariah global diperkirakan akan mencapai US\$ 3 Triliun. ${ }^{1}$

Melihat perkiraan capaian ekonomi syariah global tersebut, perbankan syariah dituntut untuk mampu meningkatkan kinerjanya agar bisa ikut menikmati capaian tersebut. Banyak tantangan yang harus dihadapi untuk mencapai target tersebut. Hoesen selaku Kepala Eksekutif Pengawas Pasar Modal dari Otoritas Jasa Keuangan mengatakan bahwa terdapat tiga tantangan yang harus dihadapi diantaranya yakni penguatan lembaga keuangan syariah, pemberian literasi keuangan kepada masyarakat, dan membentuk ekosistem keuangan syariah. ${ }^{2}$

Kinerja perbankan syariah di Indonesia dalam beberapa tahun terjadi peningkatan. Hal ini dapat dilihat dari total asset yang dimiliki, dimana dalam kurun waktu 5 tahun mengalami peningkatan yang signifikan yakni dari tahun 2016 hingga Januari 2020. Pada tahun 2020 bulan Januari total aset bank syariah mencapai Rp 346.373 miliar, dimana pada tahun 2016 total aset bank syariah sebesar Rp 254.184 miliar. Dalam kurun waktu 5 tahun terjadi kenaikan sebesar $36.2 \%{ }^{3}$

Gambar 1.

Kondisi Kinerja Bank Syariah Tahun 2016-2020

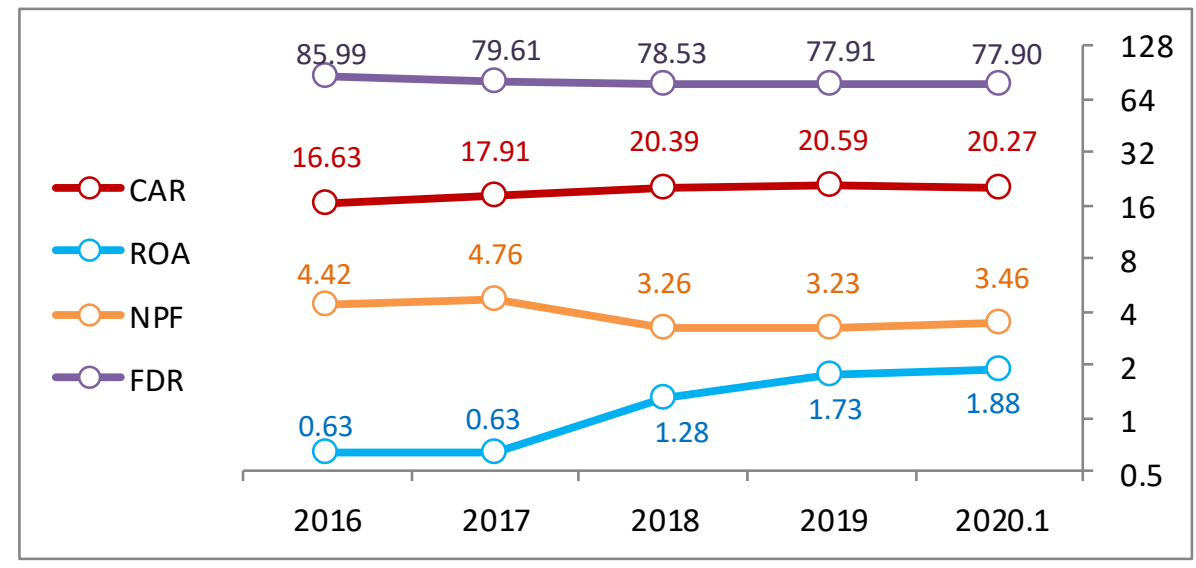

Sumber: Otoritas Jasa Keuangan (2020), Diolah Penulis

Berdasarkan gambar 1 terlihat bahwa Capital Adequacy Ratio (CAR) dalam 5 tahun terakhir mengalami peningkatan. Return on Assets (ROA) juga mengalami peningkatan dalam kurun waktu 5 tahun, dimana pada tahun 2020 bulan Januari rasio ini sebesar 1.88\%. Rasio pembiayaan bermasalah atau NPF tertinggi dalam 5 tahun terakhir yakni pada tahun 2017

\footnotetext{
${ }^{1}$ Nurhadi Sucahyo, “Kinerja Ekonomi Syariah Di Indonesia Kurang Memuaskan,” 2019, https://www.voaindonesia.com/.

${ }^{2}$ Sucahyo.

${ }^{3}$ Otoritas Jasa Keuangan, "Statistik Perbankan Syariah Januari 2020,” 2020. 
sebesar 4.76\%. Adapun rasio FDR dari 2016 mengalami penurunan yang signifikan dimana pada tahun 2020 bulan Januari rasio ini sebesar 77.90\%.

Kinerja bank dapat dijadikan sebagai tolak ukur penilaian kesehatan bank. Landasan hukum Al-Qur'an yang menjelaskan tentang perlunya penilaian tingkat kesehatan bank adalah :

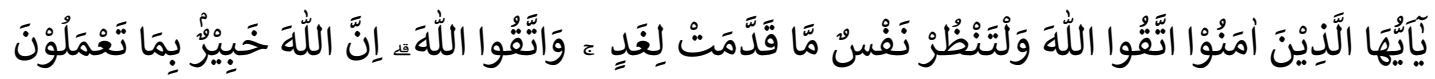

Artinya: "Wahai orang-orang yang beriman! Bertakwalah kepada Allah dan hendaklah setiap orang memperhatikan apa yang telah diperbuatnya untuk hari esok (akhirat), dan bertakwalah kepada Allah, sungguh, Allah Maha teliti terhadap apa yang kamu kerjakan".

Ayat di atas menerangkan bahwa sebagai seorang muslim kita boleh mengatur segala sesuatu yang diinginkan dan akan dilakukan pada masa yang akan datang melalui analisa kemungkinan terjadinya sebuah risiko. Jika dikaitkan pada penilaian tingkat kesehatan bank, maka bank syariah dituntut untuk mampu mengelola manajemen perusahaan dengan baik sehingga bank dapat dikategorikan sehat. Penilaian ini juga dapat menjadi landasan untuk menganalisa kekurangan pada periode ini agar dapat memperbaikinya di periode selanjutnya. Namun setelah melakukan berbagai usaha, sebagai seorang muslim hanya perlu bertawakal kepada Allah terhadap apa yang terjadi. Sebab manusia hanya mampu memprediksi dan segala sesuatu yang terjadi adalah ketetapan dari Allah.

Perkembangan perbankan syariah dapat dilakukan dengan cara meningkatkan kualitas pelayanan pada nasabah. Baik atau buruknya kualitas pelayanan bank terlihat dari tingkat kesehatan BUS itu sendiri. Berdasarkan Peraturan Bank Indonesia Nomor 6/10/PBI/2004, prosedur yang dipakai dalam mengevaluasi tingkat kesehatan bank yakni menggunakan metode CAMEL. Lalu di tahun 2011 BI mengeluarkan Surat Edaran BI Nomor 13/24/DNDP mengenai prosedur evaluasi tingkat kesehatan bank yang menerapkan sistem RBBR. Setelah fungsi pengawasan BI berpindah ke OJK, yakni sejak tanggal 1 Juli 2014, metode RBBR syariah digunakan sebagai prosedur menilai kesehatan bagi Bank Umum Syariah. Berlandaskan pada POJK No. 8/POJK.03/2014, metode yang dipakai untuk menilai kesehatan BUS yakni metode RGEC.

Rasio keuangan digunakan untuk aspek penilaian tingkat kesehatan bank. Pada penelitian ini metode RGEC digunakan dalam menilai kesehatan bank, dimana rasio yang digunakan meliputi rasio NPF dan FDR sebagai aspek risk profile, kemudian aspek GCG diproksikan dengan variabel Ukuran Dewan Komisaris (UDK). Pada aspek earnings digunakan rasio ROA atau Return on Assets. Sedangkan rasio CAR atau Capital Adequacy Ratio digunakan untuk menilai kesehatan bank dalam aspek capital.

Fungsi dari perbankan syariah yakni sebagai lembaga intermediari dengan berbagai produk yang diberikan, salah satunya yakni produk pembiayaan. Produk pembiayaan yang disalurkan menggunakan berbagai akad, diantaranya seperti akad murabahah, mudharabah, musyarakah, ijarah, dan lain sebagainya. Pada bulan September 2019, penyaluran pembiayaan dengan jumlah tertinggi yakni menggunakan akad murabahah mencapai Rp 119.916 Miliar. Berikutnya adalah akad musyarakah dengan total pembiayaan yang 
disalurkan mencapai Rp 75.859 Miliar, mengalami peningkatan sebesar 24,3\% dari tahun sebelumnya. ${ }^{4}$

Direktur Perbankan Syariah OJK yakni Dede Firman mengemukakan bahwa perkembangan pembiayaan yang positif tak sejalan dengan kemajuan kinerjanya. Hal ini dikarenakan pembiayaan bermasalah masih tinggi. Tingginya rasio NPF dikarenakan pembiayaan syariah berkaitan erat dengan sektor riil. Pada tahun tersebut, perkembangan sektor riil agak tersendat, sehingga rasio NPF masih tinggi. ${ }^{5}$ Pada aspek risiko profil, kesehatan bank juga dapat dinilai dengan menggunakan faktor risiko likuiditas. Faktor risiko likuiditas ini dianalogikan dengan FDR. Dimana dalam rasio ini, ketika total pembiayaan yang disalurkan tinggi, sehingga keuntungan yang diperoleh oleh bank juga tinggi.

Tata kelola perusahaan menjadi salah satu indeks penilaian tingkat kesehatan bank. Tata kelola perusahaan atau GCG adalah sistem yang mengatur suatu hubungan antara organorgan dalam perusahaan yang meliputi Dewan Komisaris, Direksi, serta pemangku kepentingan lainnya. Dewan Komisaris merupakan bagian inti tata kelola perusahaan dimana dalam menjalankan tugasnya Dewan Komisaris dituntut untuk mampu menjamin terlaksananya akuntabilitas perusahaan, menjamin terlaksananya strategi perusahaan, serta melakukan pengawasan terhadap manajemen dalam pengelolaan perusahaan. ${ }^{6}$ Selain itu, Dewan Komisaris bertanggungjawab untuk mengawasi pelaksanaan GCG, memastikan GCG telah dilaksanakan oleh perusahaan serta memberi arahan kepada para direksi. ${ }^{7}$ Berdasarkan hal tersebut, maka penilaian GCG dapat dinilai dengan Ukuran Dewan Komisaris.

Salah satu aspek dalam menilai kesehatan bank adalah aspek rentabilitas. Dalam menilai kesehatan bank, aspek rentabilitas dapat diproksikan dengan ROA. Rasio ROA dalam bank dipakai dalam menilai kapasitas bank dalam memperoleh profit dari kegiatan investasi. ${ }^{8}$ Selain itu, aspek lain yang digunakan untuk menilai kesehatan bank yakni aspek permodalan. Rasio yang digunakan untuk memproksikan aspek permodalan yakni CAR. Rasio ini menunjukkan persentase besarnya aktiva bank yang mengandung risiko (misalnya angsuran, piutang, surat berharga dan lain-lain) yang digunakan untuk membiayai modal bank itu sendiri, selain dana yang diperoleh dari sumber eksternal seperti hutang atau dana tabungan masyarakat. ${ }^{9}$

Dalam menjalankan operasional usaha, setiap bank harus bisa menjaga dan meningkatkan kesehatan bank melalui penerapan manajemen risiko. ${ }^{10}$ Bank yang kondisi kesehatannya baik akan meningkatkan kepercayaan nasabah maupun investor. Penilaian kesehatan bank dianggap amat penting sebab bank merupakan lembaga intermediari yang berperan dalam pengelolaan dana pihak ketiga. Oleh sebab itu, perbaikan sistem perbankan

\footnotetext{
${ }^{4}$ Otoritas Jasa Keuangan, “Statistik Perbankan Syariah September 2019,” 2019.

${ }^{5}$ Estu Suryowati, "Ini Alasan Pembiayaan Macet Perbankan Syariah Cukup Tinggi," 2017, https://www.kompas.com/.

${ }^{6}$ FCGI, "Peranan Dewan Komisaris Dan Komite Audit Dalam Pelaksanaan Corporate Governance (Tata Kelola Perusahaan)," 2001.

${ }^{7}$ KNKG, "Pedoman Umum Good Corporate Governance Indonesia," 2006.

${ }^{8}$ Irham Fahmi, Manajemen Risiko: Teori, Kasus, Dan Solusi (Bandung: Alfabeta, 2010).

${ }^{9}$ Nurimansyah Setivia Bakti, "Analisis DPK, CAR, ROA, Dan NPF Terhadap Pembiayaan Pada Perbankan Syariah,” Jurnal Bisnis \& Manajemen 17, no. 2 (2017): 15-28.

${ }^{10}$ Otoritas Jasa Keuangan, "Peraturan Otoritas Jasa Keuangan No. 08/POJK.03/2014 Tentang Penilaian Tingkat Kesehatan Bank Umum Syariah Dan Unit Usaha Syariah” (2014).

Iqtishadia: Jurnal Ekonomi dan Perbankan Syariah
}

Vol. 8 No. 1 Juni 2021 
harus selalu ditingkatkan agar kepercayaan masyarakat terhadap industri perbankan meningkat dan profesionalitas dalam pelayanan bank juga meningkat.

Banyak penelitian yang membahas mengenai kinerja bank syariah seperti penelitian yang dilakukan oleh Nassreddine, Fatma \& Anis ${ }^{11}$ dan Usman \& Khan ${ }^{12}$ yang menganalisis determinan kinerja bank serta penelitian Choong, Thim \& Kyzy ${ }^{13}$ yang melakukan studi empiris mengenai kinerja bank syariah di Malaysia. Namun masih sedikit penelitian yang meneliti tentang pengaruh tingkat kesehatan bank terhadap jumlah pembiayaan yang disalurkan. Pada beberapa hal terdapat perbedaan antara penelitian ini dengan penelitian sebelumnya. Pertama, penelitian ini menggunakan metode penilaian tingkat kesehatan yang paling baru yang diterapkan di Indonesia yakni metode RGEC, dimana dalam penelitian sebelumnya yakni penelitian Hosen \& Muhari ${ }^{14}$ masih menggunakan metode CAMELS. Kedua, dalam penelitian Andriyanto \& Prastika ${ }^{15}$ aspek penilaian management atau Good Corporate Governance tidak diikutsertakan, dimana dalam penelitian ini aspek GCG diproksikan dengan Ukuran Dewan Komisaris. Ketiga, dalam hal rentang waktu atau periode yang digunakan dalam penelitian ini yakni dimulai pada tahun 2012 dimana tahun itu merupakan awal penerapan RBBR berbasis RGEC. Hal ini dapat digunakan untuk melihat seberapa efektif metode RGEC dalam menilai kesehatan bank. Terakhir, berbeda dengan penelitian Hosen \& Muhari16 yang meneliti beberapa Bank Umum Syariah, sedangkan penelitian ini menggunakan seluruh BUS yang beroperasi di Indonesia sebagai sampel penelitian. Dengan menggunakan sampel seluruh BUS di Indonesia maka akan didapatkan hasil yang lebih mencerminkan kondisi kesehatan bank secara keseluruhan.

\section{METODE PENELITIAN}

Penelitian ini menggunakan pendekatan kuantitatif asosiatif, yakni untuk membuktikan adanya pengaruh diantara variabel $\mathrm{X}$ terhadap variabel $\mathrm{Y}$. Variabel $\mathrm{X}$ yang digunakan meliputi NPF, FDR, UDK, ROA, dan CAR. Sedangkan variabel Y dalam penelitian ini yakni total pembiayaan. Data penelitian didapatkan dari laporan triwulan BUS yang diterbitkan di situs resmi bank selama periode 2012Q1-2020Q1.

\section{Sampel}

${ }^{11}$ Nassreddine, Fatma, and Anis, "Determinants of Banks Performance: Viewing Test by Cognitive Mapping Technique (Case of BIAT)," International Journal of Contemporary Economics and Administratvie Sciences 3, no. 1 (2013): 22-46.

${ }^{12}$ Abid Usman and Muhammad Kashif Khan, "Evaluating the Financial Performance of Islamic and Conventional Banks of Pakistan: A Comparative Analysis," International Journal of Business and Social Science 3, no. 7 (2012): 253-57.

${ }^{13}$ Yap Voon Choong, Chan Kok Thim, and Bermet Talasbek Kyzy, "Performance of Islamic Commercial Banks in Malaysia: An Empirical Study," Journal of Islamic Economics, Banking and Finance 8, no. 2 (2012): 67-80.

${ }^{14}$ Muhamad Nadratuzzaman Hosen and Syafaat Muhari, "The Comparison of Soundness Level of Islamic Banks in Indonesia and Malaysia," Etikonomi 17, no. 1 (2018): 111-22.

${ }^{15}$ Irsad Andriyanto and Aprilia Inge Prastika, "Pengaruh Rasio Kesehatan Bank Terhadap Volume

Pembiayaan Bank Umum Syariah Di Indonesia," MALIA: Journal of Islamic Banking and Finance 2, no. 1 (2018): 1-16.

${ }^{16}$ Hosen and Muhari, "The Comparison of Soundness Level of Islamic Banks in Indonesia and Malaysia." 
Sampel penelitian ini meliputi seluruh Bank Umum Syariah di Indonesia, yakni 14 BUS. Adapun sampel penelitian ini disebutkan pada tabel 1 berikut:

Tabel 1

Sampel Penelitian

\begin{tabular}{cl}
\hline No. & \multicolumn{1}{c}{ Nama Bank } \\
\hline 1. & Bank Syariah Mandiri \\
2. & Bank Victoria Syariah \\
3. & Bank BRI Syariah \\
4. & Bank Panin Dubai Syariah \\
5. & Bank Muamalat Indonesia \\
6. & BCA Syariah \\
7. & Bank BNI Syariah \\
8. & Bank Mega Syariah \\
9. & Bank Syariah Bukopin \\
10. & Maybank Syariah \\
11. & Bank Jabar Banten Syariah \\
12. & Bank Aceh Syariah \\
13. & Bank Tabungan Pensiunan Nasional Syariah \\
14. & Bank NTB Syariah \\
\hline Sumber: Diolah Penulis
\end{tabular}

\section{Variabel dan Pengukurannya}

Variabel dan pengukurannya pada penelitian ini baik variabel bebas maupun variabel terikat yakni sebagai berikut :

Tabel 2

Variabel dan Pengukurannya

\begin{tabular}{ll}
\hline \multicolumn{1}{c}{ Variabel } & \multicolumn{1}{c}{ Pengukuran } \\
\hline Non Performing Financing (NPF) & NPF $=\frac{\text { Pembiayaan Bermasalah }}{\text { Total Pembiayaan }} \times 100 \%$ \\
Financing to Deposit Ratio (FDR) & FDR $=\frac{\text { Total Pembiayaan }}{\text { Total DPK }} \times 100 \%$ \\
Ukuran Dewan Komisaris (UDK) & $\begin{array}{l}\text { Ukuran Dewan Komisaris }=\text { jumlah anggota } \\
\text { Dewan Komisaris }\end{array}$ \\
Return on Assets (ROA) & ROA $=\frac{\text { Laba sebelum pajak }}{\text { Total Asset }} \times 100 \%$ \\
Capital Adequacy Ratio (CAR) & CAR $=\frac{\text { Modal Bank }}{\text { ATMR }}$ \\
Total Pembiayaan (Y) & $\begin{array}{l}\text { Total pembiayaan }=\text { jumlah seluruh } \\
\text { pembiayaan yang disalurkan }\end{array}$ \\
\hline
\end{tabular}

Sumber : Diolah Penulis 


\section{Teknik Analisis Data}

Teknik analisis dengan metode regresi data panel digunakan sebagai teknik analisis data pada penelitian ini. Adapun model regresinya dalam bentuk log linier yakni sebagai berikut :

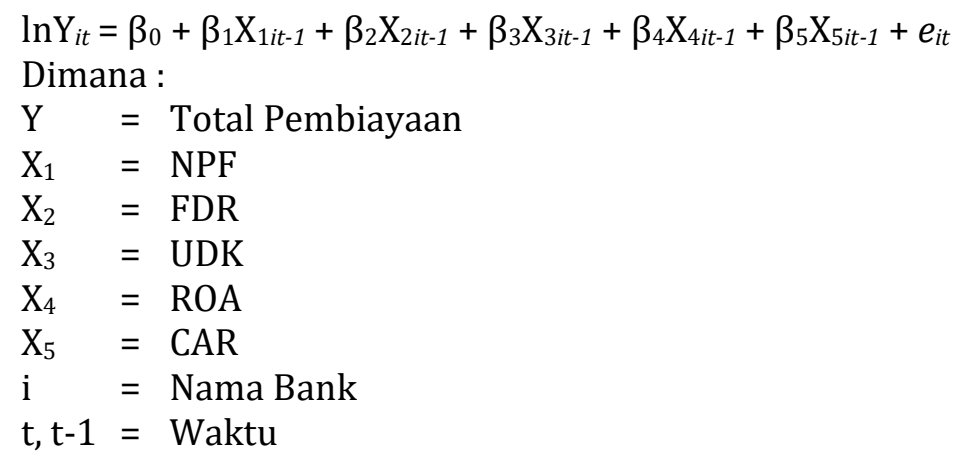

\section{HASIL DAN PEMBAHASAN}

Hasil Uji Spesifikasi Model

Uji Chow

Pemilihan model yang tepat dalam mengelola data panel dimulai dengan uji chow yang bertujuan untuk memilih model mana yang lebih tepat antara model common effect atau model fixed effect. Hasil uji chow dengan menggunakan eviews 10 ditunjukkan dalam tabel 3 berikut:

Tabel 3

Hasil Uji Chow

\begin{tabular}{llll}
\hline \hline Effects Test & Statistic & d.f. & Prob. \\
\hline \hline Cross-section F & 30.796233 & $(13,443)$ & 0.0000 \\
Cross-section Chi-square & 298.814585 & 13 & 0.0000 \\
\hline \hline
\end{tabular}

Sumber: Output Eviews 10, data diolah

Tabel 3 memperlihatkan bahwa nilai prob. chi-square yakni 0.0000. Nilai prob. chisquare lebih rendah dari $0.05(0.000<0.05)$. Artinya dalam uji ini $\mathrm{H}_{0}$ ditolak dan $\mathrm{H}_{1}$ diterima. Maka model yang lebih baik digunakan yakni fixed effect model.

Uji Hausman

Uji ini merupakan lanjutan dari uji chow. Jika pada uji chow model yang terpilih yakni fixed effect, maka tahap kedua yakni uji hausman yang bertujuan memilih model mana yang lebih baik antara random effect atau fixed effect. Hasil uji ditunjukkan pada tabel 4 berikut: 
Tabel 4

Hasil Uji Hausman

\begin{tabular}{llll}
\hline \hline Test Summary & Chi-Sq. Statistic & Chi-Sq. d.f. & Prob. \\
\hline \hline Cross-section random & 26.562307 & 5 & 0.0001 \\
\hline \hline
\end{tabular}

Sumber: Output Eviews 10, Diolah Penulis

Tabel 4 menunjukkan bahwa nilai prob. cross-section random yakni 0.0001 dimana nilai tersebut lebih kecil dari 0.05 . Artinya dalam uji ini $\mathrm{H}_{0}$ tidak diterima dan $\mathrm{H}_{1}$ diterima. Maka dalam penelitian ini model terbaik yang digunakan untuk mengelola data panel adalah FEM.

Hasil Uji Regresi Data Panel

Hasil uji regresi ditunjukkan dalam tabel 5 berikut:

Tabel 5

Hasil Uji Regresi Data Panel

\begin{tabular}{|c|c|c|c|c|}
\hline Variable & Coefficient & Std. Error & $\mathrm{t}$-Statistic & Prob. \\
\hline $\mathrm{C}$ & 12.75943 & 1.351641 & 9.439951 & 0.0000 \\
\hline NPF & 4.500376 & 4.903374 & 0.917812 & 0.3592 \\
\hline FDR & -0.000393 & 0.000676 & -0.580918 & 0.5616 \\
\hline UDK & -0.419682 & 0.358111 & -1.171933 & 0.2419 \\
\hline ROA & 7.836970 & 4.538776 & 1.726670 & 0.0849 \\
\hline CAR & -0.466972 & 0.747871 & -0.624401 & 0.5327 \\
\hline
\end{tabular}

Sumber: Output Eviews 10, Diolah Penulis

Berdasarkan tabel 5, persamaan model regresi data panel pada penelitian ini dapat ditulis seperti berikut:

$\ln Y=12.75943+4.5003 X_{1 i t-1}-0.0003 X_{2 i t-1}-0.4196 X_{3 i t-1}+7.8369 X_{4 i t-1}-0.4669 X_{5 i t-1}$

\section{Uji Hipotesis}

Uji T

Berdasarkan tabel 5 dapat diketahui dan disimpulkan hasil uji T dari masing-masing variabel yakni seperti berikut:

1. Nilai prob. NPF lebih tinggi daripada taraf signifikansi $(0.3592>0.05)$. Artinya variabel NPF tidak berpengaruh terhadap total pembiayaan.

2. Nilai prob. FDR lebih tinggi daripada taraf signifikansi $(0.5616>0.05)$. Artinya variabel FDR tidak berpengaruh terhadap total pembiayaan.

3. Nilai prob. UDK lebih tinggi daripada taraf signifkansi (0.2419>0.05). Artinya variabel UDK tidak berpengaruh terhadap total pembiayaan.

Iqtishadia: Jurnal Ekonomi dan Perbankan Syariah 
4. Nilai prob. ROA lebih tinggi daripada taraf signifikansi $(0.0849>0.05)$. Artinya variabel ROA tidak berpengaruh terhadap total pembiayaan.

5. Nilai prob. CAR lebih tinggi daripada taraf signifikansi $(0.5327>0.05)$. Artinya variabel CAR tidak berpengaruh terhadap total pembiayaan.

Uji F

Tabel 6

Hasil Uji F

\begin{tabular}{ll}
\hline \hline R-squared & 0.487283 \\
F-statistic & 23.39024 \\
Prob(F-statistic) & 0.000000 \\
\hline \hline
\end{tabular}

Sumber: Output Eviews 10, data diolah

Pada tabel 6 ditunjukkan bahwa nilai prob. F-statistic adalah 0.000 . Nilai probabilitas F-statistic dalam penelitian ini lebih kecil daripada taraf signifikansi $(0.0000<0.05)$. Artinya variabel bebas yang meliputi NPF, FDR, UDK, ROA, dan CAR berpengaruh secara simultan terhadap total pembiayaan.

Uji Koefisien Determinasi $\left(\mathrm{R}^{2}\right)$

Uji koefisien determinasi menunjukkan nilai R-squared adalah 0.4872 , artinya $48.72 \%$ variabel Y memengaruhi variabel X dalam model. Sedang sisanya dipengaruhi oleh variabel lain diluar model penelitian ini.

\section{Pengaruh NPF terhadap Total Pembiayaan}

Pembiayaan bermasalah pada bank syariah digambarkan dengan rasio NPF (NonPerforming Financing), dimana pada bank konvensional biasa disebut rasio kredit macet. Dalam menjalankan operasionalnya, bank harus meminimalisir adanya risiko pembiayaan bermasalah. Hal ini sesuai dengan QS al-Baqarah ayat 195:

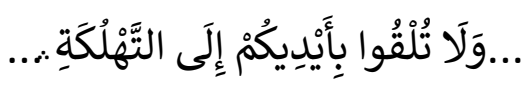

Artinya: “...dan janganlah kamu menjatuhkan dirimu sendiri dalam kebinasaan..."(QS alBaqarah 2:195)

Surat al-Baqarah ayat 195 diatas menjelaskan bahwa bank syariah perlu untuk melakukan pengelolaan kegiatan usahanya secara hati-hati dengan tujuan untuk menghindari terjadinya risiko pembiayaan bermasalah. Hal ini juga sesuai dengan kaidah fiqh 'la dharara wa la dhirara" yang maknanya adalah kita tidak diperbolehkan untuk melakukan sesuatu yang membahayakan diri sendiri maupun orang lain.

Hasil yang diperoleh pada penelitian ini adalah NPF tidak berpengaruh pada total pembiayaan Bank Umum Syariah. Terdapat beberapa hal yang menyebabkan NPF tidak berpengaruh terhadap total pembiayaan, diantaranya yakni tingginya permintaan pembiayaan di Bank Syariah. Permintaan pembiayaan yang cukup tinggi terlihat dari rasio FDR bank syariah yang relatif tinggi. Meskipun kebijakan kredit diperketat, jika rasio FDR 
tinggi maka permintaan pembiayaan oleh masyarakat juga tetap tinggi. Hal ini menunjukkan posisi tawar perbankan syariah lebih kuat dibanding posisi nasabah. Selain itu, kemampuan manajemen perbankan syariah dalam menangani pembiayaan bermasalah di bank syariah dapat menjadi alasan NPF tidak berpengaruh terhadap total pembiayaan. Penanganan pembiayaan bermasalah dilakukan dengan berbagai cara seperti reschedulling, reconditioning, dan pengaturan ulang pembiayaan dalam bentuk pembiayaan al-qardul hasan. Kondisi di perbankan syariah yang menunjukkan potensi pembiayaan bermasalah yang tinggi dapat ditangani dengan berbagai cara tersebut sehingga rasio NPF dapat ditekan. Hal ini menjadi keunggulan perbankan syariah yang dapat meningkatkan permintaan pembiayaan oleh masyarakat. ${ }^{17}$

Hasil penelitian ini sesuai dengan hasil penelitian Ali \& Miftahurrohman ${ }^{18}$ serta Permataningayu \& Mahdaria. ${ }^{19}$ Hasil penelitian Permataningayu \& Mahdaria menunjukkan bahwa rasio NPF tidak berpengaruh terhadap jumlah pembiayaan BUS di Indonesia. Sedangkan dalam penelitian Ali \& Miftahurrohman, nilai NPF yang digunakan dalam penelitian bukan angka NPF yang menjadi target pihak manajemen bank tetapi angka NPF riil yang didapatkan selama periode penelitian. Sehingga volume pembiayaan dalam penelitian ini tidak dipengaruhi oleh rasio NPF.

\section{Pengaruh FDR terhadap Total Pembiayaan}

Salah satu komponen dalam profil risiko yakni risiko likuiditas. Risiko likuiditas pada bank syariah dapat dilihat salah satunya memakai rasio FDR. Bank syariah dituntut untuk mampu meminimalisir adanya risiko tersebut. Hal ini sesuai dengan kaidah fiqh yang berbunyi "ad-dhararu yuzalu" yang bermakna bahwa sebagai seorang muslim kita harus meninggalkan kemudharatan yang akan membawa dampak negatif berupa kerugian pada diri sendiri. Maksud dari kaidah fiqh tersebut adalah dalam menjalankan operasional perbankan, bank syariah harus mengimplementasikan prinsip kehati-hatian dengan tujuan untuk mengurangi kemungkinan risiko yang terjadi.

Total penyaluran pembiayaan oleh bank pada periode ini memiliki pengaruh terhadap jumlah pembiayaan yang disalurkan pada periode selanjutnya. Ketika rasio FDR naik maka total pembiayaan yang diberikan bank juga akan bertambah. Tingginya rasio FDR menggambarkan bahwa penggunaan dana bank untuk pembiayaan disalurkan dengan volume yang besar. Hal ini dikarenakan ketika dana yang didapatkan bank meningkat maka bank harus harus mampu mengelola dana tersebut dengan cara menyalurkannya dalam bentuk pembiayaan dengan tujuan menghindari terjadinya idle fund. Jika terjadi idle fund

\footnotetext{
${ }^{17}$ Pratin and Akhyar Adnan, "Analisis Hubungan Simpanan, Modal Sendiri, NPL, Prosentase Bagi Hasil Dan Markup Keuntungan Terhadap Pembiayaan Pada Perbankan Syariah Studi Kasus Pada Bank Muamalat Indonesia (BMI)," SINERGI, 2005, 35-52.

${ }^{18}$ Herni Ali and Miftahhurrohman, "Determinan Yang Mempengaruhi Pembiayaan Murabahah Pada Perbankan Syariah Di Indonesia,” Esensi:Jurnal Bisnis Dan Manajemen 6, no. 1 (2016): 31-44.

${ }^{19}$ Gupita Permataningayu and Siti Mahdaria, "The Effect of Non-Performing Financing and Financing to Deposit Ratio on Islamic Banks Financing in Indonesia," Asian Journal of Islamic Management (AJIM) 1, no. 1 (2019): 28-37.
} 
maka akan terjadi kerugian pada bank sebab bank harus menyiapkan anggaran penyimpanan yang lebih besar dimana hal ini tidak seimbang dengan laba yang didapatkan. ${ }^{20}$

Hasil uji regresi data panel menunjukkan bahwa FDR tidak berpengaruh terhadap total pembiayaan Bank Umum Syariah. Artinya, peningkatan ataupun penurunan rasio FDR tidak memberikan pengaruh terhadap jumlah pembiayaan yang disalurkan.

Hasil penelitian ini sesuai dengan hasil penelitian Endriana ${ }^{21}$ serta Rimadhani \& Erza $^{22}$. Hasil dari penelitian Endriana menunjukkan bahwa FDR tidak memengaruhi jumlah pembiayaan BUS. Hal ini dikarenakan rata-rata nilai FDR bank umum syariah telah berada pada batas optimal yakni berkisar antara 78\% - 92\%. Sehingga faktor ini tidak menjadi hal utama para manajemen bank syariah dalam pengambilan keputusan terkait penyaluran pembiayaan. Sedang penelitian Rimadhani \& Erza memperlihatkan efek yang tidak signifikan antara FDR terhadap jumlah pembiayaan di Bank Syariah Mandiri. Artinya, efektivitas fungsi intermediari yang rendah pada Bank Syariah mandiri yang digambarkan dengan rasio FDR tidak memiliki pengaruh terhadap total pembiayaan.

\section{Pengaruh Ukuran Dewan Komisaris terhadap Total Pembiayaan}

Salah satu pemegang peranan krusial dalam melaksanakan tata kelola perusahaan yang baik adalah Dewan Komisaris. Tugas utamanya yakni menjamin terlaksananya strategi bank, memonitor pengelolaan manajemen dalam bank, dan menjamin terlaksananya akuntabilitas. Menurut Forum for Corporate Governance (FCGI), Dewan komisaris adalah inti dari kekuatan dan keberhasilan dari suatu bank. Hal ini dikarenakan Dewan Komisaris memegang tanggung jawab untuk mengawasi, memberikan petunjuk serta arahan kepada pengelola perusahaan agar mampu menumbuhkan daya saing perusahaan serta meningkatkan efisiensinya. ${ }^{23}$

Peran yang dipegang oleh Dewan komisaris harus dilaksanakan dengan penuh tanggung jawab dan bersifat amanah. Hal tersebut sesuai dengan QS al-Anfal ayat 27 sebagai berikut:

$$
\text { (َ.... }
$$

Artinya : "...dan (juga) janganlah kamu menghianati amanat-amanat yang dipercayakan kepadamu, sedang kamu mengetahui." (QS al-Anfal 8:27)

Surat al-Anfal ayat 27 menjelaskan bahwa sebagai seorang muslim kita dilarang untuk menghianati amanat yang telah dipercayakan kepada kita. Sama halnya dengan amanat yang dipegang oleh Dewan Komisaris. Maka dalam menjalankan tugasnya, Dewan Komisaris harus amanah dan bertanggungjawab.

\footnotetext{
${ }^{20}$ Andriyanto and Prastika, "Pengaruh Rasio Kesehatan Bank Terhadap Volume Pembiayaan Bank Umum Syariah Di Indonesia."

${ }^{21}$ Endriana, "Analisis Pengaruh Non Performing Financing Dan Financing to Deposit Ratio Terhadap Volume Pembiayaan Pada Perbankan Syariah Di Indonesia Dengan Dana Pihak Ketiga Sebagai Variabel Mediasi," JRKA 1, no. 1 (2015): 14-28.

${ }^{22}$ Mustika Rimadhani and Osni Erza, "Analisis Variabel-Variabel Yang Mempengaruhi Pembiayaan Murabahah Pada Bank Syariah Mandiri Periode 2008.01-2011.12,” Media Ekonomi 19, no. 1 (2011): $27-52$.

${ }^{23}$ FCGI, "Peranan Dewan Komisaris Dan Komite Audit Dalam Pelaksanaan Corporate Governance (Tata Kelola Perusahaan)."
} 
Hasil uji t pada penelitian ini memperlihatkan bahwa aspek Good Corporate Governance (GCG) yang digambarkan dengan variabel UDK tidak berpengaruh terhadap total pembiayaan Bank Umum Syariah periode 2012Q1-2020Q1. Dalam sampel penelitian ini selama periode 2012Q1-2020Q1, nilai terkecil data UDK yakni 1 (satu orang) dan nilai terbesar yakni 6 (enam orang).

Semakin banyak jumlah Dewan Komisaris yang ada pada suatu bank diharapkan dapat membuat kualitas pengambilan keputusan semakin baik pula sehingga akan memengaruhi jumlah pembiayaan yang disalurkan. Kondisi yang terjadi pada Bank Umum Syariah yang diteliti adalah meskipun jumlah Dewan Komisaris semakin banyak namun tidak memengaruhi jumlah pembiayaan yang disalurkan oleh bank.

Hasil penelitian ini sama dengan hasil penelitian Fitriani \& Hapsari. ${ }^{24}$ Penelitian tersebut meneliti mengenai pengaruh GCG dan CSR terhadap kinerja keuangan pada perusahaan yang bergerak di bidang perbankan. Salah satu penilaian faktor GCG yakni Dewan Komisaris Independen. Adapun hasil yang didapatkan membuktikan bahwa aspek GCG yaitu Dewan Komisaris Independen tidak berpengaruh secara signifikan pada kinerja keuangan di perusahaan perbankan. Artinya, penambahan banyak Komisaris Independen tidak bisa menaikkan kinerja keuangan perusahaan perbankan.

\section{Pengaruh ROA terhadap Total Pembiayaan}

ROA adalah gambaran tingkat rentabilitas dari sebuah bank. Dalam hadist riwayat alBukhari disebutkan bahwa dalam menjalankan bisnis, tidak terdapat ketentuan yang melarang seorang muslim dalam memaksimalkan profit yang didapatkan serta tidak terdapat aturan yang memberikan batas kepada seorang pebisnis dalam mengambil keuntungan. Begitu pula dengan operasional dalam Bank Syariah, dimana perbankan syariah bebas memaksimalkan labanya, namun dalam menjalankan kegiatan operasionalnya harus tetap sesuai dengan ketentuan syariah.

Secara umum, pada operasional bank ketika nilai ROA mengalami peningkatan, maka pembiayaan yang disalurkan juga akan meningkat. Namun penelitian ini menunjukkan hasil yang berbeda dimana nilai probabilitas rasio ROA dalam penelitian ini lebih besar dibanding taraf signifikansi, artinya ROA tidak memberikan dampak pada total pembiayaan Bank Umum Syariah. Hal itu dikarenakan terdapat beberapa pendanaan yang lebih diprioritaskan selain pendanaan kredit. ROA yang diinvestasikan pada aset tetap dapat digunakan untuk pertumbuhan perusahaan. Selain itu, ROA juga tidak menjadi sumber utama yang digunakan untuk mendanai penyaluran pembiayaan, banyaknya pembiayaan yang disalurkan oleh bank tidak dipengaruhi oleh naik turunnya rasio ROA. ${ }^{25}$

Hasil penelitian ini menyimpulkan bahwa rasio ROA tidak memiliki pengaruh terhadap total pembiayaan yang disalurkan. Hal ini dikarenakan ROA bukan merupakan salah satu komponen utama yang memengaruhi besar atau kecilnya pembiayaan yang disalurkan oleh bank. Namun, tidak berpengaruhnya rasio ROA terhadap total pembiayaan yang

\footnotetext{
${ }^{24}$ Luthfilia Desy Fitriani and Dini Wahyu Hapsari, "Pengaruh Good Corporate Governance Dan Corporate Social Responsibility Terhadap Kinerja Keuangan Perusahaan (Studi Pada Perbankan Milik Pemerintah Dan Swasta Yang Terdaftar Di BEI Tahun 2011-2013)," E-Proceeding of Management 2, no. 3 (2015): 3458-74. ${ }^{25}$ Ayank Narita Dyatama and Imamudin Yuliadi, "Determinan Jumlah Pembiayaan Bank Syariah Di Indonesia," Jurnal Ekonomi Dan Studi Pembangunan 16, no. 1 (2015): 73-83. 
disalurkan bukan berarti kinerja bank kurang baik. Hal tersebut dikarenakan terdapat faktor lain yang yang lebih dominan memengaruhi pembiayaan yang disalurkan. ${ }^{26}$

Penelitian ini mendapatkan hasil yang sesuai dengan hasil penelitian Adzimatinur $\mathrm{dkk}^{27}$ dan Permatasari \& Yulianto ${ }^{28}$. Hasil penelitian Permatasari \& Yulianto menyatakan bahwa ROA tidak mempunyai pengaruh pada pembiayaan. Adapun Adzimatinur dkk dalam penelitiannya menyatakan bahwa rasio ROA tidak berpengaruh secara signifikan terhadap pembiayaan. Hal ini disebabkan sumber dana pembiayaan berasal dari DPK, sehingga keuntungan yang diperoleh bank tidak disalurkan sebagai pembiayaan.

\section{Pengaruh CAR terhadap Total Pembiayaan}

Capital Adequacy Ratio (CAR) adalah rasio permodalan yang digunakan untuk menunjang aktivitas operasional sebuah bank maupun untuk menunjang mungkinnya terjadi sebuah kerugian. Dalam menjalankan sebuah bisnis, modal merupakan aspek penting. Hal ini sesuai dengan QS Ali Imran ayat 14 sebagai berikut:

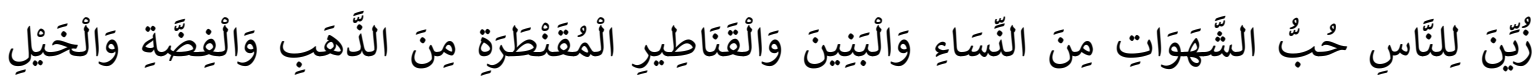

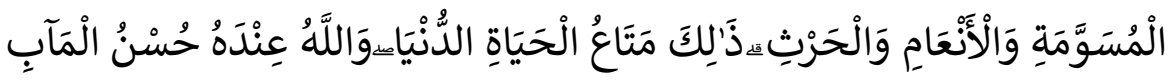

Artinya : "Dijadikan indah pada (pandangan) manusia kecintaan kepada apa-apa yang diingini, yaitu: wanita-wanita, anak-anak, harta yang banyak dari jenis emas, perak, kuda pilihan, binatang-binatang ternak dan sawah ladang. Itulah kesenangan hidup di dunia, dan di sisi Allah-lah tempat kembali yang baik (surga)." (QS Ali Imran 3:14)

Surat Ali Imran ayat 14 tersebut jika dikaitkan dengan aspek permodalan maka perhiasan berupa emas dan perak dalam ayat tersebut digunakan sebagai alat motivasi. Alat motivasi disini dimaksudkan untuk mendorong pelaku bisnis agar selalu berupaya untuk mengelola dan mengembangkan modal yang dimilikinya. Begitu pula dengan perbankan syariah dimana dalam kegiatan operasionalnya Bank Syariah dituntut untuk mampu mengelola dan mengembankan modalnya dengan baik.

Hasil uji regresi pada penelitian ini memperlihatkan bahwa nilai probabilitas CAR lebih besar dari taraf signifikansi, sehingga CAR tidak memiliki pengaruh terhadap total pembiayaan. Hasil penelitian ini selaras dengan penelitian dari Wardiantika \& Kusumaningtias $^{29}$. Hasil dari penelitian tersebut menunjukkan bahwa CAR tidak memiliki pengaruh pada pembiayaan murabahah. CAR pada bank masih berada pada batasan yang sesuai dengan ketentuan yang dibuat oleh Bank Indonesia. Sehingga tidak terdapat pengaruh dari variabel CAR terhadap jumlah pembiayaan yang diberikan.

\footnotetext{
${ }^{26}$ Bakti, “Analisis DPK, CAR, ROA, Dan NPF Terhadap Pembiayaan Pada Perbankan Syariah.”

${ }^{27}$ Fauziyah Adzimatinur, Sri Hartoyo, and Ranti Wiliasih, "Faktor-Faktor Yang Memengaruhi Besaran Pembiayaan Perbankan Syariah Di Indonesia," Al-Muzara'ah 3, no. 2 (2015): 106-21.

${ }^{28}$ Devi Permatasari and Ahmad Rudi Yulianto, “Analisis Kinerja Keuangan : Kemampuan Bank Syariah Dalam Penyaluran Pembiayaan,” Jurnal Akuntansi Indonesia 7, no. 1 (2018): 69-79.

${ }^{29}$ Lifstin Wardiantika and Rohmawati Kusumaningtias, "Pengaruh DPK, CAR, NPF, Dan SWBI Terhadap Pembiayaan Murabahah Pada Bank Umum Syariah Tahun 2008-2012,” Jurnal Ilmu Manajemen 2, no. 4 (2014): 1550-61.
} 
Hasil penelitian ini sesuai dengan penelitian Dyatama \& Yuliadi ${ }^{30}$ dan Puspitasari \& Ernawati ${ }^{31}$. Kedua penelitian tersebut menyebutkan bahwa CAR tidak memengaruhi penyaluran pembiayaan, sehingga banyaknya pembiayaan yang disalurkan oleh bank tidak dipengaruhi oleh naik maupun turunnya rasio CAR. Dalam penelitian Permatasari \& Yulianto CAR tidak mempunyai pengaruh pada penyaluran pembiayaan dikarenakan pada penelitian tersebut Bank Syariah lebih memfokuskan rasio NPF dibanding rasio CAR dalam pengambilan keputusan terkait jumlah pembiayaan yang disalurkan. Sehingga ketika rasio NPF tinggi maka BUS akan memikirkan ulang jika ingin melakukan penambahan jumlah pembiayaan yang disalurkan karena dirasa ada permasalahan dalam hal pembiayaan.

\section{Pengaruh NPF, FDR, UDK, ROA, dan CAR terhadap Total Pembiayaan}

Hasil uji f dalam penelitian ini menunjukkan variabel NPF, FDR, UDK, ROA dan CAR berpengaruh secara simultan pada total pembiayaan Bank Umum Syariah pada periode 2012Q1-2020Q1. Artinya, variabel dalam penelitian ini secara bersama-sama memberikan pengaruh terhadap meningkatnya ataupun menurunnya total pembiayaan yang disalurkan.

Variabel-variabel independen yang ada pada penelitian ini digunakan untuk menggambarkan aspek-aspek dalam penialian kesehatan bank dengan menggunakan metode RGEC. Variabel tersebut diantaranya yakni risk profile yang dianalogikan dengan NPF dan FDR, Good Corporate Governance yang digambarkan dengan UDK, earnings yang digambarkan dengan ROA, dan capital yang diproksikan dengan CAR. Secara simultan, hasil penelitian yang didapatkan membuktikan bahwa tingkat kesehatan bank berpengaruh terhadap total pembiayaan bank umum syariah di Indonesia. Semakin baik hasil penilaian tingkat kesehatan bank, maka akan terjadi peningkatan pada total pembiayaan yang disalurkan BUS. Hal ini dikarenakan tingkat kesehatan bank yang baik menunjukkan kemampuan bank yang baik dalam mengelola manajemen dan operasionalnya, sehingga penyaluran pembiayaan dapat dimaksimalkan.

Penelitian ini mendapatkan hasil yang selaras dengan hasil penelitian Bakti ${ }^{32}$. Penelitian tersebut menunjukkan bahwa variabel bebas yang meliputi DPK, CAR, ROA dan NPF memiliki pengaruh terhadap pembiayaan perbankan syariah. Selain itu, hasil penelitian Andriyanto \& Prastika ${ }^{33}$ juga menunjukkan hasil yang sama, dimana penelitian tersebut mendapatkan hasil yang memperlihatkan adanya pengaruh secara simultan dari variabel NPF, FDR, CAR, ROA dan BOPO terhadap total pembiayaan.

\section{PENUTUP}

Hasil yang didapatkan dalam penelitian ini mengungkapkan bahwa tingkat kesehatan bank yang diukur menggunakan metode RGEC yang diproksikan dengan variabel NPF, FDR, UDK, ROA dan CAR memiliki pengaruh secara simultan pada total pembiayaan. Sedangkan secara parsial variabel NPF, FDR, UDK, ROA dan CAR tidak berpengaruh terhadap total pembiayaan Bank Umum Syariah periode 2012Q1-2020Q1.

\footnotetext{
${ }^{30}$ Dyatama and Yuliadi, "Determinan Jumlah Pembiayaan Bank Syariah Di Indonesia."

${ }^{31}$ Filia Puspitasari and Endang Ernawati, "Pengaruh Mekanisme Corporate Governance Terhadap Kinerja Keuangan Badan Usaha,” Jurnal Manajemen Teori Dan Terapan 3, no. 2 (2010): 189-215.

32 Bakti, “Analisis DPK, CAR, ROA, Dan NPF Terhadap Pembiayaan Pada Perbankan Syariah.”

33 Andriyanto and Prastika, "Pengaruh Rasio Kesehatan Bank Terhadap Volume Pembiayaan Bank Umum Syariah Di Indonesia."
} 
Variabel yang digunakan dalam penelitian ini masih terbatas, sehingga peneliti memberikan rekomendasi kepada peneliti selanjutnya untuk menambah aspek lain dalam model penelitian guna menyempurnakan penelitian ini. Aspek lain tersebut misalnya aspek eksternal dari bank seperti tingkat inflasi, kondisi ekonomi negara, dan perubahan kurs. Selain itu, sampel dalam penelitian juga dapat diperluas dengan menambahkan Unit Usaha Syariah yang beroperasi di Indonesia. Hal ini ditujukan agar penelitian memperoleh hasil yang akurat.

\section{DAFTAR PUSTAKA}

Adzimatinur, Fauziyah, Sri Hartoyo, and Ranti Wiliasih. "Faktor-Faktor Yang Memengaruhi Besaran Pembiayaan Perbankan Syariah Di Indonesia." Al-Muzara'ah 3, no. 2 (2015): 106-21.

Ali, Herni, and Miftahhurrohman. "Determinan Yang Mempengaruhi Pembiayaan Murabahah Pada Perbankan Syariah Di Indonesia." Esensi:Jurnal Bisnis Dan Manajemen 6, no. 1 (2016): 31-44.

Andriyanto, Irsad, and Aprilia Inge Prastika. "Pengaruh Rasio Kesehatan Bank Terhadap Volume Pembiayaan Bank Umum Syariah Di Indonesia." MALIA: Journal of Islamic Banking and Finance 2, no. 1 (2018): 1-16.

Bakti, Nurimansyah Setivia. "Analisis DPK, CAR, ROA, Dan NPF Terhadap Pembiayaan Pada Perbankan Syariah." Jurnal Bisnis \& Manajemen 17, no. 2 (2017): 15-28.

Choong, Yap Voon, Chan Kok Thim, and Bermet Talasbek Kyzy. "Performance of Islamic Commercial Banks in Malaysia: An Empirical Study." Journal of Islamic Economics, Banking and Finance 8, no. 2 (2012): 67-80.

Dyatama, Ayank Narita, and Imamudin Yuliadi. "Determinan Jumlah Pembiayaan Bank Syariah Di Indonesia." Jurnal Ekonomi Dan Studi Pembangunan 16, no. 1 (2015): 73-83.

Endriana. "Analisis Pengaruh Non Performing Financing Dan Financing to Deposit Ratio Terhadap Volume Pembiayaan Pada Perbankan Syariah Di Indonesia Dengan Dana Pihak Ketiga Sebagai Variabel Mediasi." JRKA 1, no. 1 (2015): 14-28.

Fahmi, Irham. Manajemen Risiko: Teori, Kasus, Dan Solusi. Bandung: Alfabeta, 2010.

FCGI. "Peranan Dewan Komisaris Dan Komite Audit Dalam Pelaksanaan Corporate Governance (Tata Kelola Perusahaan)," 2001.

Fitriani, Luthfilia Desy, and Dini Wahyu Hapsari. "Pengaruh Good Corporate Governance Dan Corporate Social Responsibility Terhadap Kinerja Keuangan Perusahaan (Studi Pada Perbankan Milik Pemerintah Dan Swasta Yang Terdaftar Di BEI Tahun 2011-2013)." EProceeding of Management 2, no. 3 (2015): 3458-74.

Hosen, Muhamad Nadratuzzaman, and Syafaat Muhari. "The Comparison of Soundness Level of Islamic Banks in Indonesia and Malaysia." Etikonomi 17, no. 1 (2018): 111-22.

KNKG. “Pedoman Umum Good Corporate Governance Indonesia,” 2006.

Nassreddine, Fatma, and Anis. "Determinants of Banks Performance: Viewing Test by Cognitive Mapping Technique (Case of BIAT)." International Journal of Contemporary Economics and Administratvie Sciences 3, no. 1 (2013): 22-46.

Otoritas Jasa Keuangan. Peraturan Otoritas Jasa Keuangan No. 08/POJK.03/2014 Tentang Penilaian Tingkat Kesehatan Bank Umum Syariah dan Unit Usaha Syariah (2014).

___. "Statistik Perbankan Syariah Januari 2020," 2020.

———. "Statistik Perbankan Syariah September 2019," 2019. 
Permataningayu, Gupita, and Siti Mahdaria. "The Effect of Non-Performing Financing and Financing to Deposit Ratio on Islamic Banks Financing in Indonesia." Asian Journal of Islamic Management (AJIM) 1, no. 1 (2019): 28-37.

Permatasari, Devi, and Ahmad Rudi Yulianto. "Analisis Kinerja Keuangan : Kemampuan Bank Syariah Dalam Penyaluran Pembiayaan." Jurnal Akuntansi Indonesia 7, no. 1 (2018): 6979.

Pratin, and Akhyar Adnan. "Analisis Hubungan Simpanan, Modal Sendiri, NPL, Prosentase Bagi Hasil Dan Markup Keuntungan Terhadap Pembiayaan Pada Perbankan Syariah Studi Kasus Pada Bank Muamalat Indonesia (BMI)." SINERGI, 2005, 35-52.

Puspitasari, Filia, and Endang Ernawati. "Pengaruh Mekanisme Corporate Governance Terhadap Kinerja Keuangan Badan Usaha." Jurnal Manajemen Teori Dan Terapan 3, no. 2 (2010): 189-215.

Rimadhani, Mustika, and Osni Erza. "Analisis Variabel-Variabel Yang Mempengaruhi Pembiayaan Murabahah Pada Bank Syariah Mandiri Periode 2008.01-2011.12." Media Ekonomi 19, no. 1 (2011): 27-52.

Sucahyo, Nurhadi. "Kinerja Ekonomi Syariah Di Indonesia Kurang Memuaskan," 2019. https://www.voaindonesia.com/.

Suryowati, Estu. "Ini Alasan Pembiayaan Macet Perbankan Syariah Cukup Tinggi," 2017. https://www.kompas.com/.

Usman, Abid, and Muhammad Kashif Khan. "Evaluating the Financial Performance of Islamic and Conventional Banks of Pakistan: A Comparative Analysis." International Journal of Business and Social Science 3, no. 7 (2012): 253-57.

Wardiantika, Lifstin, and Rohmawati Kusumaningtias. "Pengaruh DPK, CAR, NPF, Dan SWBI Terhadap Pembiayaan Murabahah Pada Bank Umum Syariah Tahun 2008-2012." Jurnal Ilmu Manajemen 2, no. 4 (2014): 1550-61. 